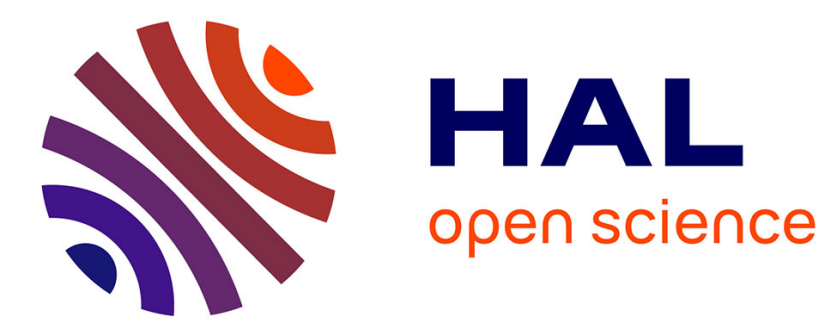

\title{
Radial growth changes following hemlock woolly adelgid infestation of eastern hemlock
}

\author{
David M. Walker, Carolyn A. Copenheaver, Audrey Zink-Sharp
}

\section{To cite this version:}

David M. Walker, Carolyn A. Copenheaver, Audrey Zink-Sharp. Radial growth changes following hemlock woolly adelgid infestation of eastern hemlock. Annals of Forest Science, 2014, 71 (5), pp.595602. 10.1007/s13595-014-0367-3 . hal-01102601

\section{HAL Id: hal-01102601 https://hal.science/hal-01102601}

Submitted on 13 Jan 2015

HAL is a multi-disciplinary open access archive for the deposit and dissemination of scientific research documents, whether they are published or not. The documents may come from teaching and research institutions in France or abroad, or from public or private research centers.
L'archive ouverte pluridisciplinaire $\mathbf{H A L}$, est destinée au dépôt et à la diffusion de documents scientifiques de niveau recherche, publiés ou non, émanant des établissements d'enseignement et de recherche français ou étrangers, des laboratoires publics ou privés. 


\title{
Radial growth changes following hemlock woolly adelgid infestation of eastern hemlock
}

\author{
David M. Walker • Carolyn A. Copenheaver • \\ Audrey Zink-Sharp
}

Received: 26 October 2013 / Accepted: 27 February 2014 /Published online: 14 March 2014

(C) INRA and Springer-Verlag France 2014

\begin{abstract}
- Context Hemlock woolly adelgid (Adelges tsugae) is an invasive insect that is defoliating and killing eastern hemlock (Tsuga canadensis) in the USA.

- Aims We quantified changes in tree-ring growth rates and wood anatomy for living trees infested with hemlock woolly adelgid across six sites from Massachusetts $\left(42^{\circ} 41^{\prime} \mathrm{N}\right)$ to Georgia $\left(34^{\circ} 53^{\prime} \mathrm{N}\right)$ to identify growth responses of eastern hemlock that had survived infestation.

- Methods Annual ring widths from infested eastern hemlocks were cross-dated and measured. Growth rates before and after infestation were compared. Two infested trees from Virginia were cut, and thin sections were prepared to identify changes in cell properties.

- Results At three sites, trees experienced a significant decrease in radial growth after hemlock woolly adelgid arrival; however, the other three sites showed no change or increase in growth. Latewood produced after hemlock woolly adelgid infestation had significantly smaller cells with reduced cell wall thickness compared to latewood prior to infestation.

- Conclusion At half the sites where hemlock woolly adelgid infested eastern hemlock trees were sampled, radial growth increased or remained unchanged. This unexpected response may be due to reduced competition due to mortality of other eastern hemlocks or physiological compensatory responses of increased photosynthetic rate and increased water use
\end{abstract}

\section{Handling Editor: Francois Lieutier}

D. M. Walker $\cdot$ C. A. Copenheaver $(\bowtie)$

Department of Forest Resources and Environmental Conservation,

Virginia Tech, Blacksburg, VA 24061, USA

e-mail: ccopenhe@vt.edu

A. Zink-Sharp

Department of Sustainable Biomaterials, Virginia Tech, Blacksburg, VA 24061, USA efficiency experienced by eastern hemlock infested with hemlock woolly adelgid.

Keywords Adelges tsugae · Dendrochronology · Tree rings · Tsuga canadensis

\section{Introduction}

Hemlock woolly adelgid (Adelges tsugae Annand, HWA) is a small, aphid-like insect originally from Japan that feeds on the foliage of eastern hemlock (Tsuga canadensis (L.) Carriere) and is causing substantial mortality to this important tree species throughout eastern North America (Evans et al., 2011; Orwig and Foster, 1998). Hemlock woolly adelgid was first discovered on eastern hemlock in a city park near Richmond, Virginia in the early 1950s, and because the insect reproduces two times per year, it has spread at an average rate of $12.5 \mathrm{~km} \mathrm{yr}^{-1}$ and now spans from the southernmost limit of eastern hemlock to close to its northern limit (Evans and Gregoire, 2007; Souto et al., 1996). The widespread death of eastern hemlock caused by HWA represents the loss of a foundation species from eastern forests and the loss of an invaluable archive of paleoenvironmental tree-ring records from one of the longest-lived tree species in eastern temperate forests (Hessl and Pederson, 2013).

Given eastern hemlock's late successional status and its responsiveness to climate, most eastern hemlock tree-ring studies have focused on reconstructing stand dynamics or reconstructing climate-growth relationships (Abrams et al., 2000; Hart et al., 2010); however, the introduction of HWA provides an unusual opportunity to study the decline and mortality of a foundation species through its tree-ring record. Previous studies on other insect-defoliated trees have shown a consistent pattern of reduced radial growth following infestation because the consumption of foliage results in a loss of 
stored carbohydrates and lower potential photosynthetic rates (Vejpustkova and Holusa, 2006). These reductions in growth within the host species are typically accompanied by growth increases in non-host trees as mortality of the host species increases availability of light, space, and nutrients (Alfaro et al., 1991). Eastern hemlock is the primary host of HWA, and mortality of eastern hemlock in infested stands ranges from 5 to $>95 \%$ (Orwig and Foster, 1998). Therefore, the tree rings from eastern hemlock that survive the infestation should record both the impacts to growth during the infestation and the shift in environmental conditions after the death of surrounding eastern hemlocks.

Hemlock woolly adelgid feeds by attaching to the base of eastern hemlock needles, where it inserts its stylet bundle into the twig xylem and extracts stored sugars, hindering the tree's ability to grow (Young et al., 1995). Although HWA feeds on eastern hemlock foliage from fall through late winter, it is winter feeding by HWA on stored carbohydrates that is particularly harmful if cold winter temperatures prevent eastern hemlock from photosynthesizing and replacing lost resources (Hadley et al., 2008). Short-term extraction of stored carbohydrates would be damaging to the tree, but unlikely to cause death. However, it is hypothesized that HWA saliva contains a toxin that causes a hypersensitive response to feeding, and results in premature needle drop, discoloration and thinning of foliage, and branch tip dieback and, typically, death within 4 to 15 years (Eschtruth et al., 2006; Radville et al., 2011).

Eastern hemlock that survives HWA infestation is left in a forest stand that is very different from pre-HWA conditions. Eastern hemlock is being replaced as a dominant species by deciduous trees such as black birch (Betula lenta L.), red maple (Acer rubrum L.), tulip poplar (Liriodendron tulipifera L.), and several oak (Quercus) species (Ford et al., 2012; Orwig et al., 2002). The water and nutrient balance is also substantially different as small streams dry up during the summer; soil surface temperatures increase, and precipitation throughfall increases bringing higher nitrogen and organic carbon to the forest floor (Knoepp et al., 2011; Stadler et al., 2005). The death of eastern hemlock also provides a large input of organic matter to the ecosystem, causing net nitrogen mineralization, nitrification, and nitrogen turnover to significantly increase, although soil carbon declines because of the loss of fine roots (Jenkins et al., 1999; Nuckolls et al., 2009). These changes in forest condition result in mirrored shifts in terrestrial arthropods, bird, and wildlife populations as specialists adapted to eastern hemlock stands decline by up to $70 \%$ of pre-HWA densities (Adkins and Rieske, 2013; Allen et al., 2009).

This dynamic period of transition for eastern hemlock forests caused by HWA infestation is an excellent opportunity to witness how forests respond to drastic, sudden environmental change. The species that will provide the best record for this transition will be the surviving eastern hemlock because they directly experienced the impacts of HWA. Therefore, our research objectives were to (a) reconstruct from the tree-ring record of eastern hemlock how tree growth has been altered by the introduction of HWA and (b) examine the microscopic influence of HWA on cell-level xylem production in eastern hemlock. As a secondary objective, because of the close relationship between HWA and temperature (Parker et al., 1999), we also tested for a relationship between tree-ring growth and crown dieback and temperature. It is anticipated that the results of this study will eventually be used to better predict how eastern hemlocks will adapt and change their ecological role in the forest after HWA infestation.

\section{Materials and methods}

\subsection{Study areas}

To evaluate the impact of HWA on radial growth of surviving eastern hemlock trees, we sampled trees from six study sites on publically owned land that spanned the current range of HWA infestation in the USA (Fig. 1, Table 1). Three of the study sites (North Carolina, West Virginia, and Pennsylvania) had been used in previous HWA studies (Davis et al., 2007; Evans et al., 2011; Nuckolls et al., 2009), and we were able to get the first year of HWA infestation from these studies; for the other three sites, we relied upon local land management records for the date of first HWA infestation. All sites had an overstory composed of mixed hardwood and eastern hemlock. Based on hand texturing of the soil, the soil texture from the six study sites included sandy clay loam at Georgia, Virginia, and West Virginia; sandy loam from North Carolina; loam from Pennsylvania; and loamy sand from Massachusetts.

Identification of the influence of HWA on cell-level xylem production in eastern hemlock is a more labor-intensive process in the laboratory, and therefore, we reduced our study sites to sample only from the Virginia site. We selected this site because we were permitted to destructively sample trees to collect the wood anatomy samples.

\subsection{Field and laboratory techniques}

At each site, 23 dominant or codominant eastern hemlock trees infested with HWA were cored approximately $0.5 \mathrm{~m}$ above the ground using an increment borer. Trees were categorized as being infested if HWA was detected on any living branches (Costa and Onken, 2006). Percent crown dieback of each tree was determined using the US Forest Service visual crown rating method (Montgomery et al., 2006). Two cores were extracted from each tree on opposite sides of the trunk. After air drying, increment cores were glued on wooden mounts and sanded with progressively finer grit sandpaper 


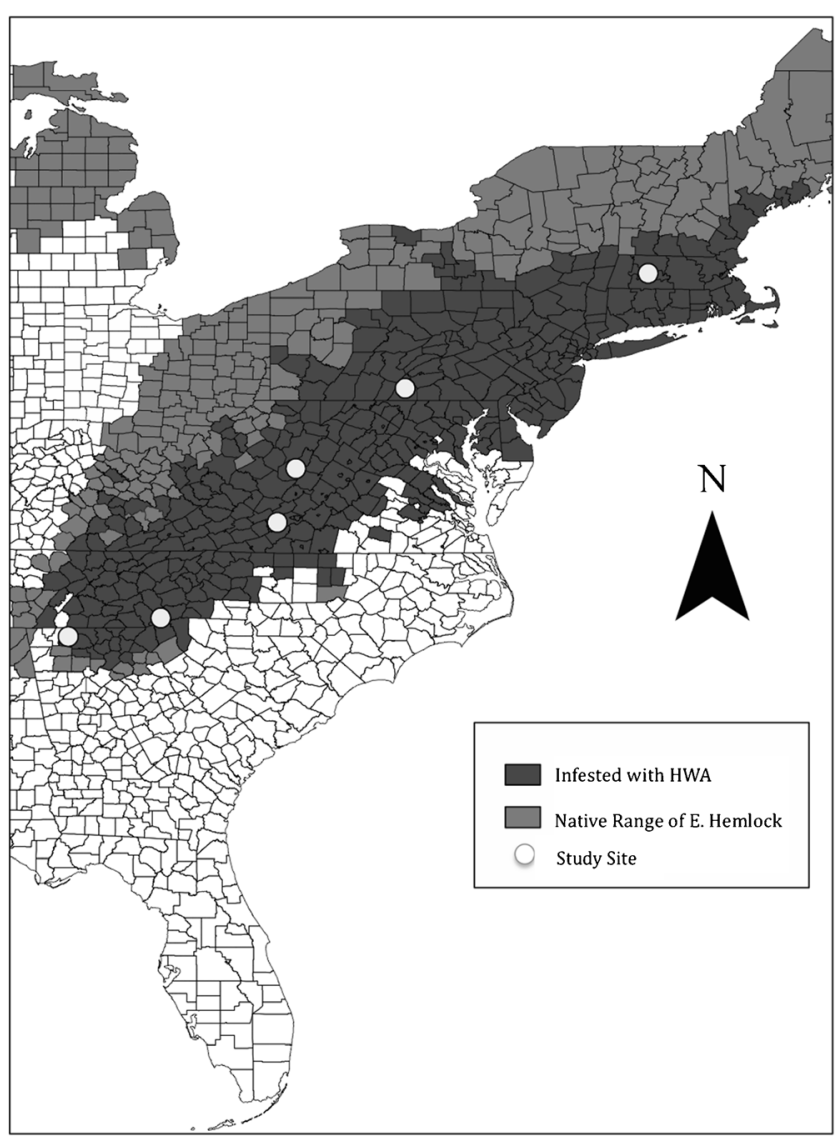

Fig. 1 Study site locations (white circles), range of eastern hemlock (gray), and 2011 range of hemlock woolly adelgid (dark gray). Adapted from USDA Forest Service 2011 hemlock woolly adelgid infestation map

until a smooth surface was achieved and cells were clearly visible under a microscope.

All cores were visually cross-dated, by site, using the list method that involves matching narrow rings common to many cores to identify missing and false rings (Yamaguchi, 1991). False rings were a particular concern because previous work with HWA-infested eastern hemlock had shown a $50 \%$ increase in false ring formation after HWA infestation (GondaKing et al., 2012). All visually cross-dated cores were then measured using either a TA Unislide Measurement System (Velmex, Inc., Bloomfield, NY) or a LINTAB 5 Measurement
System (RINNTECH, Heidelberg, Germany). Visual crossdating was statistically verified using the computer program COFECHA (available through the Dendrochronology Program Library). Cores where there was an error in visual cross-dating were re-evaluated, and dating errors were corrected.

For the analysis of microscopic changes in wood anatomy resulting from HWA, two infested eastern hemlock trees from the Virginia site were felled, and cross-sections were removed. Each cross-section was cut into 10 small cubes with 5 cubes containing wood produced prior to HWA arrival and 5 cubes containing wood produced after HWA arrival. The wood blocks were soaked in water for $24 \mathrm{~h}$, and then, thin sections $40 \mu \mathrm{m}$ thick were taken with a GSL sledge microtome $(\mathrm{H}$. Gartner, Birmensdorf, Switzerland). Thin sections were stained using a $0.5 \%$ Safranin O solution and mounted on permanent microscope slides. A light microscope and digital camera were used to capture images from the cross-sections, and the Nikon Image Systems BR software (Nikon Instruments, Tokyo) was used to measure radial tracheid diameter and cell wall thickness of earlywood and latewood cells from each thin section. Cell wall thickness was also measured in the radial direction, and these measurements yielded a total of 300 pre-HWA wood measurements (150 earlywood cells and 150 latewood cells) and 300 post-HWA wood measurements (150 earlywood cells and 150 latewood cells).

\subsection{Data analysis}

To identify HWA-related changes in mean radial growth, paired $t$ tests were used to determine if growth rates changed after HWA infestation. We averaged an equal number of annual ring widths during pre- and post-HWA infestation; thus, the number of years analyzed at each site depended on the date of HWA arrival and varied across sites (Table 1). Because the analysis computes the differences in the measurement pairs, the distribution of differences was plotted to verify the normality of the data set. The Georgia, North Carolina, Virginia, Pennsylvania, and Massachusetts sites were

Table 1 Six study sites where eastern hemlocks were sampled for evaluating the influence of hemlock woolly adelgid (HWA) on radial growth

\begin{tabular}{llllllll}
\hline Site & Latitude & Longitude & Elevation (m) & Winter temp (C) & Annual Precipation (mm) & First HWA sighting & Crown dieback (\%) \\
\hline Georgia & $34^{\circ} 53^{\prime} \mathrm{N}$ & $84^{\circ} 39^{\prime} \mathrm{W}$ & 600 & 5.2 & 1,332 & 2008 & 10 \\
North Carolina & $35^{\circ} 17^{\prime} \mathrm{N}$ & $82^{\circ} 43^{\prime} \mathrm{W}$ & 670 & 3.7 & 1,393 & 2005 & 22 \\
Virginia & $37^{\circ} 11^{\prime} \mathrm{N}$ & $80^{\circ} 29^{\prime} \mathrm{W}$ & 570 & 0.8 & 1,095 & 1998 & 15 \\
West Virginia & $38^{\circ} 37^{\prime} \mathrm{N}$ & $79^{\circ} 47^{\prime} \mathrm{W}$ & 900 & -1.8 & 1,265 & 1993 & 13 \\
Pennsylvania & $40^{\circ} 00^{\prime} \mathrm{N}$ & $77^{\circ} 48^{\prime} \mathrm{W}$ & 500 & -1.4 & 1,010 & 1993 & 15 \\
Massachusetts & $42^{\circ} 21^{\prime} \mathrm{N}$ & $72^{\circ} 22^{\prime} \mathrm{W}$ & 180 & -4.0 & 1,100 & 1996 & 10
\end{tabular}

Climate data are from the National Climatic Data Center for the period of 1895-2011. Crown dieback was measured at the time of sampling using the US Forest Service visual crown rating methods (Montgomery et al., 2006) 
normally distributed, but a $\log _{10}$ transformation was used to normalize the West Virginia site.

Differences in pre- and post-HWA latewood cell wall thickness, latewood radial tracheid diameter, earlywood cell wall thickness, and earlywood radial tracheid diameter were identified with two sample $t$ tests. To conform to the normality assumptions of this test, distributions of cell property data were plotted, and a square root transformation was necessary to normalize the earlywood cell wall thickness data —all other data sets were normally distributed. To conform to the equal variance requirement of the $t$ tests, Levene's test was used to test each data set, and all data sets met this requirement [latewood cell wall thickness $(F=0.51, p=0.475)$, latewood cell diameter $(F=3.05, p=0.082)$, earlywood cell wall thickness $(F=0.34, p=0.557)$, and earlywood cell diameter $(F=$ $1.14, p=0.231)]$.

To determine how percent crown dieback was related to HWA-impacted radial growth, a Pearson correlation coefficient was calculated between tree percent crown dieback and average annual ring width in the last three years. The period of three years was selected because eastern hemlocks retain their needles for several years, and therefore, the single year measurement of crown dieback reflected a lagged crown condition. To determine whether mean winter temperature and mean crown dieback can serve as valid predictors of change in radial growth in response to HWA infestation, multiple linear regression was used. Change in growth (growth before HWA minus growth during HWA infestation) was used as the dependent variable and mean winter temperature and mean crown dieback were used as the independent variables. Results of statistical tests were considered significant at $\alpha=$ 0.05 .

\section{Results}

3.1 HWA, climate, crown dieback, and growth interactions

During cross-dating, we did not find the frequency of false rings identified by other researchers (Gonda-King et al., 2012); however, missing rings and partial rings were very common in the years after HWA infestation (Fig. 2). No missing rings were present in any tree-ring series before HWA infestation. After HWA infestation, North Carolina had at least one missing ring in all of the sampled trees, Pennsylvania had missing rings in $45 \%$ of its trees, and Virginia had missing rings in $43 \%$ of its trees. Despite the missing and partial rings, we were able to successfully crossdate the eastern hemlock trees. The interseries correlation for each site, a measure of the strength of the common signal, ranged from 0.46 in Georgia to 0.57 in West Virginia (Table 2). North Carolina, Virginia, and Pennsylvania (the same sites that had high frequencies of missing rings) had

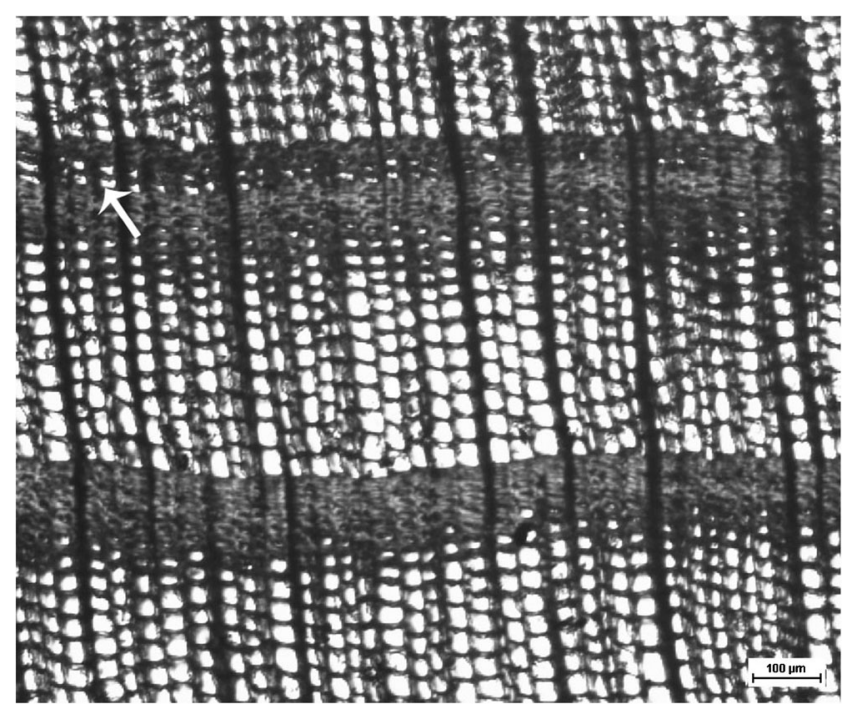

Fig. 2 Partial ring produced in eastern hemlock after HWA arrival at the site. White arrow at left indicates earlywood cells that are absent from the right side of the image

significantly narrower mean ring width post-HWA arrival compared to pre-HWA (Table 3). At a tree level, these decreases in radial growth either appear immediately after HWA infestation or are slightly delayed (Fig. 3). Georgia and West Virginia showed no statistical change in ring width as a result of HWA infestation, and eastern hemlock in Massachusetts had significantly wider ring width post-HWA arrival compared to pre-HWA (Table 3). Georgia, West Virginia, and Massachusetts also had the lowest rates of crown dieback (Table 1).

Percent crown dieback was significantly, negatively correlated with the last three years of radial growth $(r=$ $-0.34, p<0.001)$. The relationship between the mean change in radial growth pre- and post-HWA arrival and mean winter temperature and mean percent dieback had a coefficient of determination of $r^{2}=0.83$; however, only percent crown dieback was a significant predictor of change in growth $(p=0.049)$, and winter temperature was not a significant predictor $(p=0.312)$.

\subsection{HWA-caused changes in wood anatomy}

The latewood cell wall thickness of tracheids produced after HWA arrival was significantly narrower than tracheids produced pre-HWA ( $t=6.87, p<0.001$, Table 4$)$, and mean latewood radial cell diameter produced post-HWA arrival was also significantly smaller compared to cells produced prior to HWA arrival $(t=3.33, p=0.001)$. There were no significant differences in either the mean earlywood cell wall thickness or the earlywood radial diameter of tracheids produced postHWA arrival compared to those produced before HWA arrived (Table 4). 
Table 2 General characteristics of the six eastern hemlock tree-ring data sets

\begin{tabular}{|c|c|c|c|c|c|}
\hline Site & Number of trees & Mean ring width (mm) & Series intercorrelation & Mean sensitivity & Maximum tree age (years) \\
\hline Georgia & 21 & 2.97 & 0.46 & 0.20 & 65 \\
\hline North Carolina & 20 & 1.93 & 0.51 & 0.25 & 101 \\
\hline Virginia & 21 & 2.02 & 0.52 & 0.27 & 142 \\
\hline West Virginia & 20 & 1.70 & 0.57 & 0.22 & 241 \\
\hline Pennsylvania & 20 & 1.67 & 0.50 & 0.20 & 115 \\
\hline Massachusetts & 21 & 2.11 & 0.54 & 0.22 & 124 \\
\hline
\end{tabular}

\section{Discussion}

The only prior examination of radial growth response to HWA found that all eastern hemlock had below average growth after HWA arrival (Rentch et al., 2009). This earlier study was located in the Delaware Water Gap National Recreation Area, where HWA has been intensively studied since its introduction in 1993; therefore, the researchers were able to use detailed records of local infestation levels to find a connection between HWA infestation level and rate of radial growth decline. The opportunity to work in forests with detailed records of environmental history is unique, and most dendroecologists work in environments with little information about the history of the site. Thus, they must depend upon the tree-ring record to reconstruct the environmental history. This is a particularly difficult objective when working in forest stands that have experienced high mortality rates because the environmental records contained in the trees that died are no longer available to researchers (Johnson et al., 1994). In this study, we selected study sites with no existing records of HWA infestation beyond the date of arrival. Thus, we set a hard task for ourselves, but not an uncommon one, and we found some unexpected results. Although three sites (North Carolina, Virginia, and Pennsylvania) had a decline in radial growth after HWA arrival similar to the reduction at the Delaware Water Gap National Recreation Area (Rentch et al., 2009), the other three sites had very different patterns.
Massachusetts experienced a significant increase in radial growth, while West Virginia and Georgia had no significant change in growth after HWA arrival (Table 3). Rentch et al. (2009) found decreases in growth in all eastern hemlock regardless of level of infestation; therefore, the differences in response found at our sites may not be simply differences in level of infestation. Instead there may be something unique about the Massachusetts, West Virginia, and Georgia sites that allowed these trees to avoid growth suppression after HWA infestation.

Studies that show growth increases or no changes in growth rate in response to insect outbreaks are not common. Speer et al. (2010) documented tree responses to periodical cicadas (Magicicada spp.) that feed on xylem fluids and found three tree species that experienced increases in growth after cicada emergence attributed to nutrient pulses from decomposing insect carcasses. Therefore, it is possible that even if insects are detrimental to tree growth, if other environment conditions are favorable to growth, the insect damage may be "masked" by growth increases that are unrelated or indirectly related to insect activity.

The Massachusetts and West Virginia sites have the coldest winter temperatures of our six study sites (Table 1). These cold temperatures may be providing ideal growing conditions for eastern hemlocks relative to the other study sites. Cold winter temperatures increase HWA mortality, which decreases harmful winter feeding rates (Parker et al., 1999) and resulted in the

Table 3 Mean ring width before and after HWA arrival at each of the six study sites

\begin{tabular}{|c|c|c|c|c|c|c|}
\hline Site & $\begin{array}{l}\text { Years of HWA } \\
\text { infestation }\end{array}$ & $\begin{array}{l}\text { Sample size } \\
\text { (number of annual rings) }\end{array}$ & $\begin{array}{l}\text { Mean ring width before } \\
\text { HWA (mm) }\end{array}$ & $\begin{array}{l}\text { Mean ring width after } \\
\text { HWA (mm) }\end{array}$ & $t$ value & $p$ value \\
\hline Georgia & 4 & 320 & $2.83(1.23)$ & $2.71(1.32)$ & -0.72 & 0.413 \\
\hline North Carolina & 5 & 360 & $2.20(1.52)$ & $1.23(1.38)$ & -7.24 & $<0.001^{*}$ \\
\hline Virginia & 13 & 858 & $2.58(1.50)$ & $1.72(1.28)$ & -6.17 & $<0.001^{*}$ \\
\hline West Virginia & 18 & 1,396 & $1.02(0.51)$ & $1.01(0.52)$ & -0.51 & 0.612 \\
\hline Pennsylvania & 17 & 1,428 & $1.42(0.80)$ & $1.01(0.70)$ & -6.45 & $<0.001^{*}$ \\
\hline Massachusetts & 15 & 1,230 & $1.65(0.76)$ & $1.87(1.21)$ & 2.08 & $0.044^{*}$ \\
\hline
\end{tabular}

An asterisk marks the significant changes in ring width across the two time periods $(\alpha=0.05)$. The sample size relates the total number of rings included in the $t$ test - half of these rings were from before HWA arrival and half were from after HWA arrival. The values in parenthesis after the mean ring widths are standard deviations 

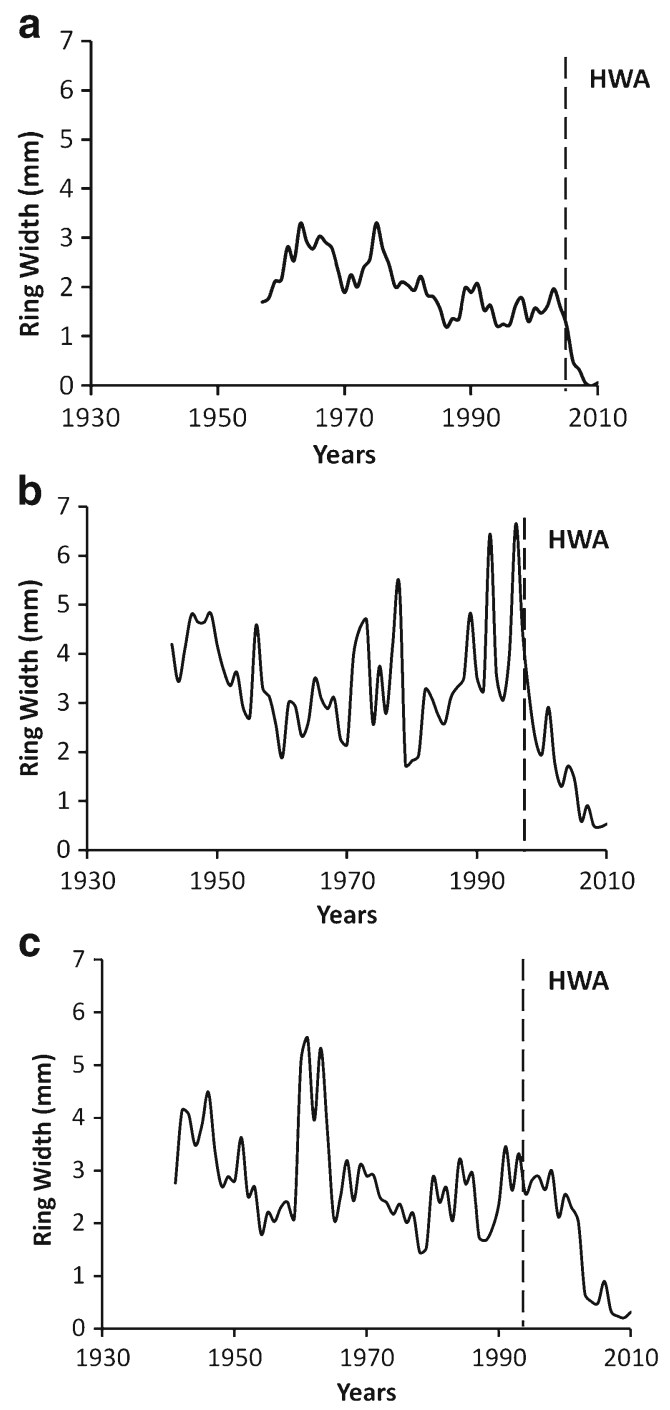

Fig. 3 Tree-ring widths from individual trees demonstrating declining growth immediately following HWA infestation (a and b) and slightly delayed after HWA infestation (c)

lower levels of crown dieback measured during sampling (Table 1). Cold winter temperatures also allow winter snow to remain on site and melt during warm spring weather when eastern hemlock radial growth benefits from high moisture availability as the trees put on new growth (Abrams et al., 2000; Hart et al., 2010). Therefore, a year with unusually cold temperatures may result in reduced HWA infestations, stored snow pack, and cooler summer temperatures, three factors that act synergistically to mask the reductions in radial growth caused by HWA feeding. Alternatively, the increased growth rates identified at Massachusetts, West Virginia, and Georgia may also reflect compensatory physiological responses experienced by eastern hemlock in response to HWA infestation. Domec et al. (2013) found that eastern hemlock infested with HWA experienced increased photosynthetic capacity and increased water use efficiency or all physiological responses that may have allowed infested eastern hemlock to experience increased growth rates.

Another potential factor that may have masked the harm of HWA in eastern hemlock growth at these three sites is the mortality of other eastern hemlock trees. Eastern hemlock is a highly competitive species and when it dominates the overstory, it is able to limit the growth of saplings and ground flora (Martin and Goebel, 2013). When such a highly competitive species is removed from a dominant position through HWA, residual trees experience a reduction in competition for light, space, and nutrients. It has been documented that co-occurring canopy trees of species other than eastern hemlock have responded to HWA mortality with increased growth rates (Ford et al., 2012). It may be that at the Massachusetts, West Virginia, and Georgia sites, the surviving eastern hemlocks were able to take advantage of these less competitive growing conditions and continue previous growth rates or increase growth rates over pre-HWA conditions.

The only study site where we were able to destructively sample trees to examine changes in wood anatomy in response to HWA infestation was the Virginia site, a site where radial growth was significantly reduced after HWA infestation. Hemlock woolly adelgid had no influence on earlywood cells, but latewood cells produced after HWA infestation had significantly narrower cell walls, and the mean cell diameter was smaller (Table 4). This is similar to the results of Domec et al. (2013) who found a reduction in cell size of HWA-infested eastern hemlock growing in North Carolina. Their North Carolina study site was located $50 \mathrm{~km}$ from our North Carolina site, where we found reductions in radial growth after HWA arrival (Table 3); thus, it is likely that the decrease in radial growth identified at both the Virginia and North

Table 4 Comparison of xylem cell properties before and after HWA arrival $(\alpha=0.05)$

\begin{tabular}{lcrr}
\hline Cell properties & Before HWA arrival & After HWA arrival & $t$ value \\
\hline Mean LW cell wall thickness $(\mu \mathrm{m})$ & $5.51(1.00)$ & $4.65(1.12)$ & 6.87 \\
Mean LW radial cell diameter $(\mu \mathrm{m})$ & $15.90(2.70)$ & $14.82(2.92)$ & $<0.001^{*}$ \\
Mean EW cell wall thickness $(\mu \mathrm{m})$ & $2.24(1.10)$ & $2.34(1.05)$ & $0.001^{*}$ \\
Mean EW radial cell diameter $(\mu \mathrm{m})$ & $50.36(8.40)$ & $51.17(8.36)$ & -0.79 \\
\hline
\end{tabular}

Values in parenthesis are standard deviations

$L W$ latewood, $E W$ earlywood 
Carolina sites is a result of smaller xylem cell size. This same reduction in cell size and cell wall thickness was found in eastern larch (Larix laricina (Du Roi) K. Koch) that had been defoliated by the larch sawfly (Pristiphora erichsonii Htg.) and European larch (Larix decidua Mill.) that had been defoliated by the European web-spinning larch sawfly (Cephalcia lariciphila Wachtl) (Filion and Cournoyer, 1995; Vejpustkova and Holusa, 2006). In years, when insect defoliation depletes the tree's resources to an extreme level, the tree may form no annual ring or may only form xylem cells incompletely around the circumference of the cambium. This may explain the high frequency of missing and partial rings we found at the three sites that experienced significant decreases in radial growth after HWA infestation (Fig. 2). This same association between insect defoliation and missing or partial rings has also been identified in balsam fir (Abies balsamea Mill.) that had been defoliated for several years by spruce budworm (Choristoneura fumiferana Clemens) (Krause and Morin, 1995).

Most previous studies examining the impact of insect damage on radial growth of trees have found a decrease in growth associated with insect outbreaks. Although we found this expected pattern in half of our study sites, the other three study sites showed an unexpected increase in growth following HWA introduction or the trees experienced no change in growth. We hypothesize that this lack of growth suppression may be due to increased resources caused by the mortality of neighboring eastern hemlock killed by HWA or the increased photosynthetic capacity and increased water use efficiency experienced by eastern hemlock infested with HWA. Cold temperatures, which reduce HWA populations in winter and increase eastern hemlock radial growth in summer, also reduce the signal of HWA feeding in the tree-ring record. Thus, it appears that the changes in stand condition caused by HWA, along with favorable temperature conditions, may mask the reduction in radial growth in some locations. This finding holds an interesting potential for future research of eastern hemlocks, which have survived the HWA introduction to eastern North America.

Acknowledgments The authors thank J.A. Peterson, J.J. Feldhaus, R.J. Kidd, M. Silsby, R. Hall, and B.J. Beale for assistance in the field.

Funding This research was supported by the USDA NIFA Special Grant No. 2010-34489-20784 and Southern Appalachian Botanical Society Earl Core Award.

\section{References}

Abrams MD, van de Gevel S, Dodson RC, Copenheaver CA (2000) The dendroecology and climatic impacts for old-growth white pine and hemlock on the extreme slopes of the Berkshire Hills, Massachusetts, U.S.A. Can J Bot 78:851-861
Adkins JK, Rieske LK (2013) Loss of a foundation forest species due to an exotic invader impacts terrestrial arthropod communities. Forest Ecol Manag 295:126-135

Alfaro RI, Liang Q, Vallentgoed J (1991) Diameter growth losses in western larch caused by larch casebearer defoliation. West J Appl For 6:105-108

Allen MC, Sheehan J, Master TL, Mulvihill R (2009) Responses of Acadian flycatchers (Empidonax virescens) to hemlock woolly adelgid (Adelges tsugae) infestation in Appalachian riparian forests. Auk 126:543-553

Costa S, Onken B. Standardizing sampling for detection and monitoring of hemlock woolly adelgid. (2006): USDA Forest Service, FHTET2006-16.

Davis DD, Fromm MS, Davis MD. Impact of the hemlock woolly adelgid on radial growth of eastern hemlock in Pennsylvania. In: Proceedings of the 15th Central Hardwood Forest Conference-Buckley DS, Clatterbuck WT, eds. (2007) Knoxville, TN. 157-162

Domec JC et al (2013) Hemlock woolly adelgid (Adelges tsugae) infestation affects water and carbon relations of eastern hemlock (Tsuga canadensis) and Carolina hemlock (Tsuga caroliniana). New Phytol 199:452-463

Eschtruth AK, Cleavitt NL, Battles JJ, Evans RA, Fahey TJ (2006) Vegetation dynamics in declining eastern hemlock stands: 9 years of forest response to hemlock woolly adelgid infestation. Can J For Res 36:1435-1450

Evans AM, Gregoire TG (2007) A geographically variable model of hemlock woolly adelgid spread. Biol Invasions 9:369-382

Evans DM, Aust WM, Dolloff CA, Templeton BS, Peterson JA (2011) Eastern hemlock decline in riparian areas from Maine to Alabama. North J Appl For 28:97-104

Filion L, Cournoyer L (1995) Variation in wood structure of eastern larch defoliated by the larch sawfly in subartic Quebec, Canada. Can J For Res 25:1263-1268

Ford CR, Elliott KJ, Clinton BD, Kloeppel BD, Vose JM (2012) Forest dynamics following eastern hemlock mortality in the southern Appalachians. Oikos 121:523-536

Gonda-King L, Radville L, Preisser EL (2012) False ring formation in eastern hemlock branches: impacts of hemlock woolly adelgid and elongate hemlock scale. Environ Entomol 41:523-531

Hadley JL, Kuzeja PS, Daley MJ, Phillips NG, Mulcahy T, Singh S (2008) Water use and carbon exchange of red oak and eastern hemlock-dominated forests in the northeastern USA: implications for ecosystem-level effects of hemlock woolly adelgid. Tree Physiol 28:615-627

Hart JL, van de Gevel S, Sakulich J, Grissino-Mayer HD (2010) Influence of climate and disturbance on the growth of Tsuga canadensis at its southern limit in eastern North America. Trees Struct Funct 24:621633

Hessl A, Pederson N (2013) Hemlock Legacy Project (HeLP): a paleoecological requiem for eastern hemlock. Prog Phys Geog 37:114 129

Jenkins JC, Aber JD, Canham CD (1999) Hemlock woolly adelgid impacts on community structure and $\mathrm{N}$ cycling rates in eastern hemlock forests. Can J For Res 29:630-645

Johnson EA, Miyanishi K, Kleb H (1994) The hazards of interpretation of static age structures as shown by stand reconstructions in a Pinus contorta - Picea engelmannii forest. J Ecol 82:923-931

Knoepp JD, Vose JM, Clinton BD, Hunter MD (2011) Hemlock infestation and mortality: impacts on nutrient pools and cycling in Appalachian forests. Soil Sci Soc Am J 75:1935-1945

Krause C, Morin H (1995) Changes in radial increment in stems and roots of balsam fir [Abies balsamea (L.) Mill] after defoliation by spruce budworm. Forest Chron 71:747-754

Martin KL, Goebel PC (2013) The foundation species influence of eastern hemlock (Tsuga canadensis) on biodiversity and ecosystem 
function on the Unglaciated Allegheny Plateau. Forest Ecol Manag 289:143-152

Montgomery ME, Onken B, Evans RA (2006) Monitoring hemlock crown health in Delaware Water Gap National Recreation Area. In: Onken B, Reardon R (eds) Third symposium on hemlock woolly adelgid in the eastern United States. USDA Forest Service, FHTET2005-01, Asheville, NC, pp 346-348

Nuckolls AE, Wurzburger N, Ford CR, Hendrick RL, Vose JM, Kloeppel BB (2009) Hemlock declines rapidly with hemlock woolly adelgid infestation impacts on the carbon cycle of southern Appalachian forests. Ecosystems 12:179-190

Orwig DA, Foster DR (1998) Forest response to the introduced hemlock woolly adelgid in southern New England. J Torrey Bot Soc 125:60 73

Orwig DA, Foster DR, Mausel DL (2002) Landscape patterns of hemlock decline in New England due to the introduction of hemlock woolly adelgid. J Biogeogr 29:1475-1487

Parker BL, Skinner M, Gouli S, Ashikaga T, Teillon HB (1999) Low lethal temperature for hemlock woolly adelgid (Homoptera: Adelgidae). Environ Entomol 28:1085-1091

Radville L, Chaves A, Preisser EL (2011) Variation in plant defense against invasive herbivores: evidence for hypersensitive response in eastern hemlock (Tsuga canadensis). J Chem Ecol 37:592-597

Rentch JS, Fajvan MA, Evans RA, Onken B (2009) Using dendrochronology to model hemlock woolly adelgid effects on eastern hemlock growth and vulnerability. Biol Invasions 11:551-563

Souto D, Luther T, Chianese B (1996) Past and current status of HWA in eastern and Carolina hemlock stands. In: Salom SM, Tigner TC, Reardon RC (eds) Proceedings of the First Hemlock Woolly
Adelgid Review. USDA Forest Service FHTET-2008-02, Charlottesville, VA, pp 9-16

Speer JH, Clay K, Bishop G, Creech M (2010) The effect of periodical cicadas on growth of five tree species in midwestern deciduous forests. Am Midl Nat 164:173-186

Stadler B, Muller T, Orwig D, Cobb R (2005) Hemlock woolly adelgid in New England forests: canopy impacts transforming ecosystem processes and landscapes. Ecosystems 8:233-247

Vejpustkova M, Holusa J (2006) Impact of defoliation caused by the sawfly Cephalcia lariciphila (Hymenoptera: Pamphilidae) on radial growth of larch (Larix decidua Mill.). Eur J For Res 125:391-396

Yamaguchi DK (1991) A simple method for cross-dating increment cores from living trees. Can J For Res 21:414-416

Young RF, Shields KS, Berlyn GP (1995) Hemlock woolly adelgid (Homoptera: Adelgidae) - stylet bundle insertion and feeding sites. Ann Entomol Soc Am 88:827-835

\section{Contribution of co-authors}

Walker (this study was his M.S. thesis project-he completed study design, field work, lab work, data analysis, and writing), Copenheaver (Walker's M.S. advisor - she assisted with study design, field work, data analysis, and writing), and Zink-Sharp (Walker's graduate committee member - she assisted with lab work and writing). 